\title{
BIRDS
}

\section{NOTEWORTHY MANITOBA BIRD SPECIMENS IN THE STEWART-HAY MEMORIAL MUSEUM AND UNIVERSITY OF MANITOBA ZOOLOGY MUSEUM}

SPENCER G. SEALY, Department of Zoology, University of Manitoba, Winnipeg, MB R3T $2 \mathrm{~N} 2$

\section{Introduction}

The Stewart-Hay Memorial Museum (SHMM) in the Department of Zoology, University of Manitoba, houses a large collection of specimens of fossil and extant invertebrates and vertebrates. The specimens were collected over many years by several people and were assembled through the mid1950 s in part by Ronald K. Stewart-Hay (1909-1962), who lectured in the Department of Zoology between 1941 and 1962. The origins of most specimens, however, are obscure and lack information on when and where they were collected. Those dates and places of collection that have been recorded must be taken at face value because the information, in most cases, cannot be confirmed. Among those specimens are approximately 600 mounted birds, many of which were collected or assembled in the late 1890 s and early 1900 s by George E. Atkinson, a taxidermist and naturalist from Portage la Prairie, Manitoba, who died in 1913. Specimens of the Barn Owl and Ivory Gull in the Stewart-Hay Museum, acquired after Atkinson's death, are the first confirmed records of these species for Manitoba and are known to ornithologists. ${ }^{2,3,5,11,23,32,44,45}$

In addition to the mounted specimens in the Stewart-Hay collection, there is a collection of study skins of birds assembled more recently to augment the collections of fish, amphibians, reptiles, and mammals that form the basis of courses in biodiversity at the University of Manitoba. I arrived at the University of Manitoba in 1972 and began building up a collection of study skins of birds for teaching and research, most of which were salvaged from various sources. Currently, there are about 3,100 specimens catalogued in this collection, housed in the University of Manitoba Zoology Museum (UMZM).

Here I present information on selected specimens in both of these collections, representing species that are vagrants, occur irregularly in Manitoba, or are important in other ways. Many of these specimens reveal the kinds of information that can be derived from collections and, hence, attest to the importance of continuing to preserve specimens of birds, and other animals. Details are provided for these specimens and, for the record, sightings of some of these species made while conducting field research in southern Manitoba, primarily at Delta Marsh, centered at the Delta Marsh Field Station (University of Manitoba), are included. Banding and sight records obtained by the Delta Marsh Bird Observatory (DMBO) also supplement some of the specimen records, and reference to specimens housed in The Manitoba Museum (MM) round out one species account. The information presented here extends our 
knowledge of these species in Manitoba, but their status in the province has been summarized in the recently published book, The Birds of Manitoba. ${ }^{23}$

\section{Annotated List of Species}

\section{Least Bittern}

The Manitoba Wildlife Rehabilitation Centre at Glenlea (all localities mentioned in the text are in Manitoba, unless stated otherwise) received a Least Bittern (UMZM
2854) found injured in Winnipeg in late summer 2003. The date accompanying the specimen was 7 September, but there is uncertainty whether the bird was actually found on that day or earlier, possibly even in late August (A. Galloway pers. comm.). Both legs had been broken at the distal ends of the tibiotarsi, which suggests it had collided with an overhead wire. It was emaciated and soon died. That it was a juvenile, with down on the crown and rectrices, suggests local nesting, but it could

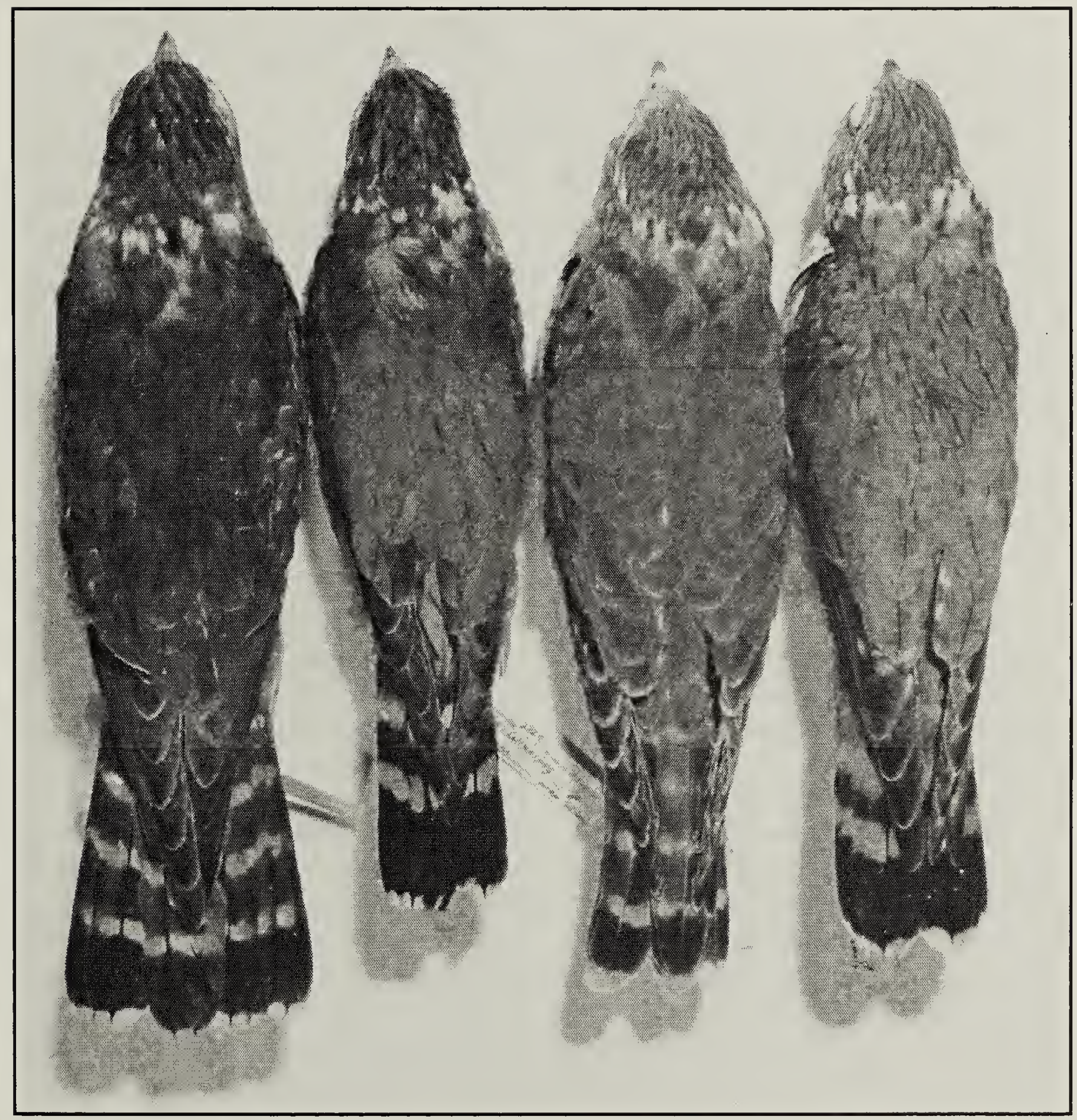

Figure 1. Adult Merlins from southern Manitoba: the bird on the extreme left (UMZM 2836, female) and the bird to its right (UMZM 2825, male) show characteristics of $\mathrm{F}$. c. columbarius, whereas the bird on the extreme right (UMZM 2829, female) and the bird to its left (UMZM 2830, male) show characteristics of $\mathrm{F}$. c. richardsonii. 
have flown from a distant nesting site, even from outside Manitoba. There are confirmed nesting records for the province and other specimens have been preserved. ${ }^{2.3}$

Percy N. Hébert, Sealy, and students in an ornithology class flushed a Least Bittern from cattails at Oak Hammock Marsh, near Stonewall, on 3 October 1988. On 25 May 1992, Paula Grieef and Sealy saw one in reeds at Delta Marsh, on the property of the Delta Waterfowl Foundation. These sightings add to the growing number of Least Bittern records in Manitoba. ${ }^{23}$

\section{Great Egret}

The Great Egret increased in numbers and expanded its range across the American midwest after the slaughter of birds for their feathers was stopped in the early 20th century. Although there is a specimen taken in Manitoba in the late 19th century, the species only began to be recorded regularly in the province during the $1950 \mathrm{~s}^{23}$ The second specimen for the province is an emaciated, immature female (UMZM 3088) brought to the Manitoba Wildlife Rehabilitation Centre on 1 September 2004 where it soon died.

\section{Surf Scoter}

The Stewart-Hay Memorial Museum catalogue lists two mounted Surf Scoters, but I located only one (SHMM 558), which, according to the catalogue, was a female taken at Clandeboye Bay, Delta Marsh. No date was given but 17 November 1928 was penciled on the bottom of the stand on which the bird was mounted, as were its age and sex (immature male) and the locality. (Coincidently, or in error, this is the same date and locality given for the mounted specimen of the Black Scoter [SHMM 560] in the next account.) This specimen is on display with other species of ducks from Manitoba. The missing specimen (SHMM 559) allegedly was a female taken on 1 October 1926 at Netley Lake. J. Nelson took an immature male Surf Scoter at Delta Marsh on 11 November 1984 that was donated to the UMZM collection, but it was destroyed when a freezer failed.

\section{Black Scoter}

A mounted, adult female Black Scoter (SHMM 560) was taken at Clandeboye Bay on Delta Marsh on 17 November 1928. Although the identity of this species was confirmed, the date and collecting locality were not (see above). D.A. Sexton shot two, one an immature male (UMZM 2418), from a flock at Delta Marsh, on Simpson Bay, on 13 October 1982. This is the rarest of the three scoters in Manitoba and especially so in southern Manitoba. ${ }^{23}$

\section{Merlin}

After a decline in numbers over much of North America between 1950 and the early 1970s, Merlins have increased dramatically in Manitoba, moving into the cities of Brandon in 1977 and Winnipeg in the 1980 s. ${ }^{23}$ By the late 1980 s, coincidental with this increase, specimens started to trickle in to the University of Manitoba Zoology Museum. In 1989, an adult female Merlin (UMZM 2836) was found dead on 17 April in Winnipeg and an adult male (UMZM 2832) was taken near Brandon on 1 October. The female had the wider black stripes on the crown and showed the darker plumage characteristic of the "Taiga" Merlin (Falco columbarius columbarius), whereas the male had thin stripes on the crown and was paler, one of the characteristics of the "Prairie" Merlin (F. c. richardsonii). ${ }^{12,42.49}$ Seventeen additional Merlins were salvaged between 1990 and 2003 and many others without data were discarded. Preservation of at least a representation of these specimens will add to our knowledge of mortality and provide potential information on sex and age of wintering individuals, plumages, and timing of molts and other events in the annual cycle.

At least two of the three subspecies of Merlin currently recognized in North America $^{42}$ are represented in the collection (Fig. 1). In addition to the specimen of the Taiga Merlin mentioned above, taken during 


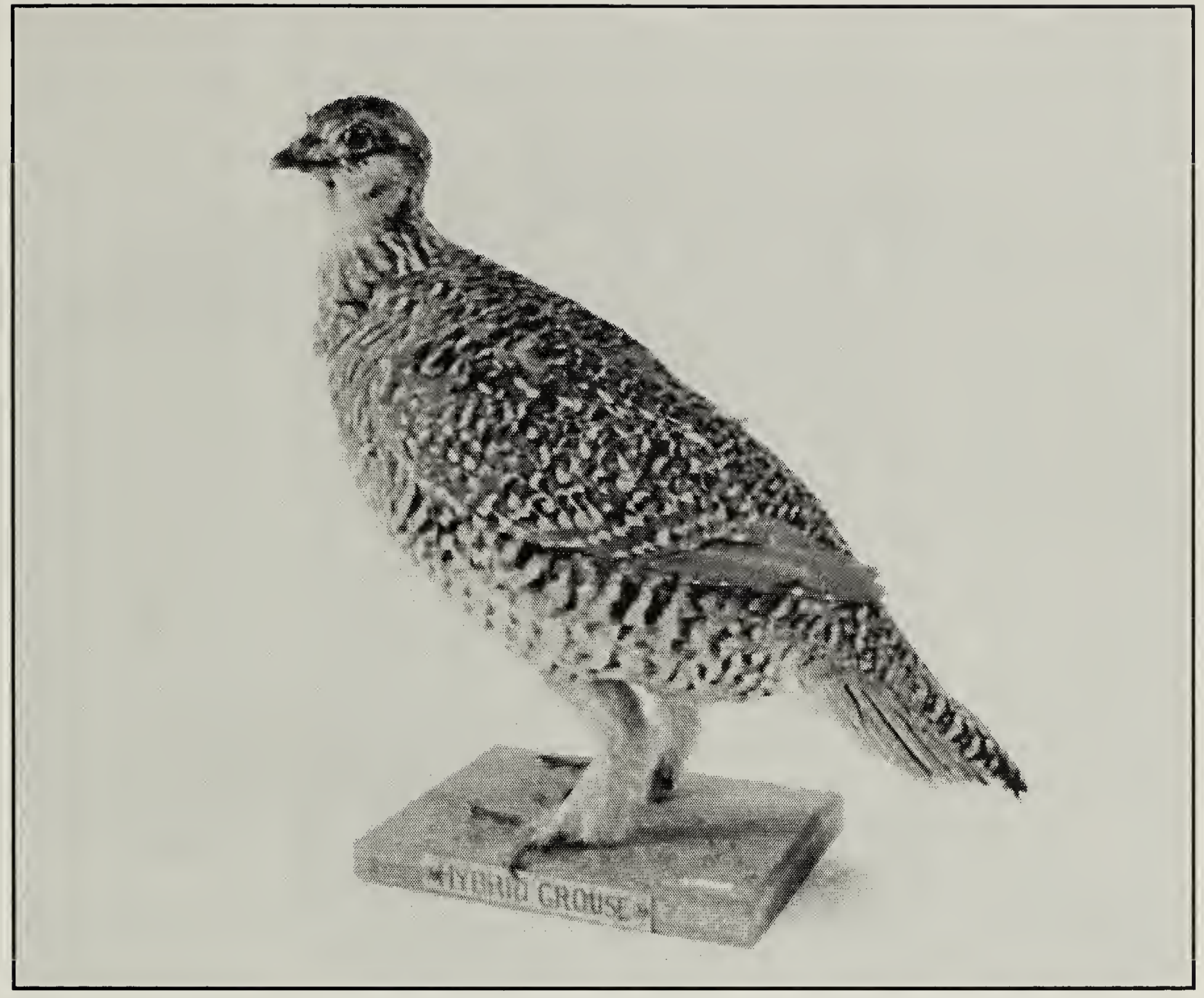

Figure 2. Hybrid Greater Prairie-Chicken x Sharp-tailed Grouse (SHMM 625), University of Manitoba.

the spring migration, four other specimens showing the characteristics of this subspecies were taken in southern Manitoba apparently during spring (UMZM 2825, 2855) and fall (UMZM 2835, 2837) migrations. The specimens of adult Prairie Merlins were taken in all seasons, which reflects the habit of at least some individuals of this subspecies remaining in southern Manitoba in winter. ${ }^{23}$ The other specimens that matched descriptions of Prairie Merlins were juveniles.

As a cautionary note, Hamilton and Schmitt (2000, p. 64) emphasized that Merlin plumages are variable, "perhaps to the point where no migrating or wintering individual can be identified to subspecies with utter confidence."12 Recently, with the advent of the tools of molecular genetics, the value of subspecies and even their validity have been seriously questioned. ${ }^{52}$

\section{Greater Prairie-Chicken}

Houston documented the spread and subsequent disappearance of the Greater Prairie-Chicken on the Canadian prairies and adjacent areas. Many specimens were taken in this region, including Manitoba. ${ }^{14}$ There are four mounted specimens in the StewartHay Memorial Museum (SHMM 587, 624, 626,628 ) and one egg alleged to be from this species (SHMM 627), but it is not known where the specimens were taken. There also is a specimen of a hybrid Greater PrairieChicken x Sharp-tailed Grouse (SHMM 625, Fig. 2) but it, too, lacks data. Three specimens of hybrids from Manitoba are preserved in The Manitoba Museum (MM 1.2-2188A, 1.2-2188B, 1.2-2757). Hybridization between Sharp-tailed Grouse and Greater Prairie-Chickens has been 


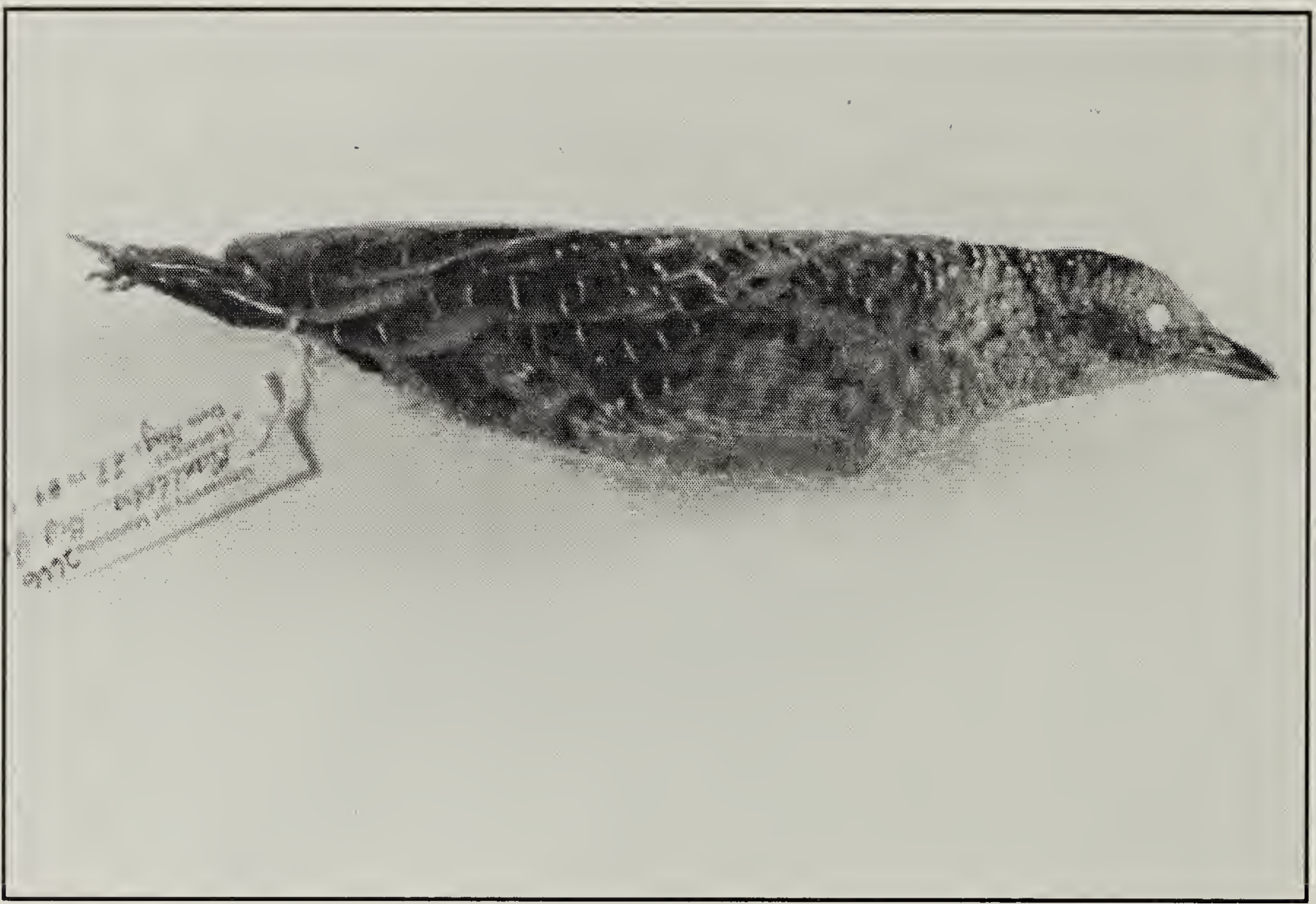

Figure 3. Yellow Rail (UMZM 2666), Big Grass Marsh, Manitoba, 27 August 1989.

recorded frequently and it may have contributed to the decline of the latter species..$^{14}$

A small-scale attempt to re-introduce Greater Prairie-Chickens from Minnesota into southern Manitoba in the early 1970s failed. ${ }^{27}$ Two females slated for this release died in captivity in November 1974 (R. B. Oetting, pers. comm.) and were preserved (UMZM 1342, 1343).

\section{Yellow Rail}

An adult male Yellow Rail (UMZM 2666), with slightly regressed testes, was among several ducks and other water birds that succumbed to botulism on Big Grass Marsh, west of Lake Manitoba, in 1989. The rail was salvaged on 27 August, relatively late in the outbreak (R.W. Nero, pers. comm.) and apparently is the only specimen (Fig. 3) from southern Manitoba, the other nine having been taken near Hudson Bay and deposited in several museums. The condition of some of the specimens from Hudson Bay suggests nesting (four males with "testes greatly enlarged" on 28 July
$1937^{10}$ and a female with a large brood patch on 21 July $1964,{ }^{15}$ ) but the only confirmed nesting records in Manitoba are from the Douglas Marsh just east of Brandon. ${ }^{17}$

\section{Whooping Crane}

A mounted adult of the endangered Whooping Crane (SHMM 672) is on display (Fig. 4) in the Stewart-Hay Memorial Museum; the date and locality of collection are not known.

\section{Piping Plover}

From 1975 through 1978, a few pairs of Piping Plover nested on the graveled surface of the west dike of the Portage Diversion, which diverts water in some years from the Assiniboine River into Lake Manitoba, shunting it through Delta Marsh. On 7 June 1975, my attention was drawn to the presence of nesting Piping Plovers at this site when I discovered a road-killed female (UMZM 1392) on the dike. Its ovary revealed that the first egg of a clutch had been laid. Subsequently, on 9 June 1975, a pair with a nest and three eggs was found; a second pair was observed on the dike that 
year but no nest was located. By mid-June the dike had been graded and the nest(s) destroyed. Single nests containing three eggs were found on the same stretch of dike on 20 June 1976, 28 May 1977, and 29 May 1978 and another pair was present in 1977 but no nest was found. These nests also failed, but renesting in 1976 is suggested as J.P. Goossen found a freshly damaged egg containing a nearly hatched embryo (UMZM 2861) on 22 July. Piping Plovers had not been observed on the dike in 1973 and 1974 and I have not seen them there since.

There are two other Piping Plover specimens

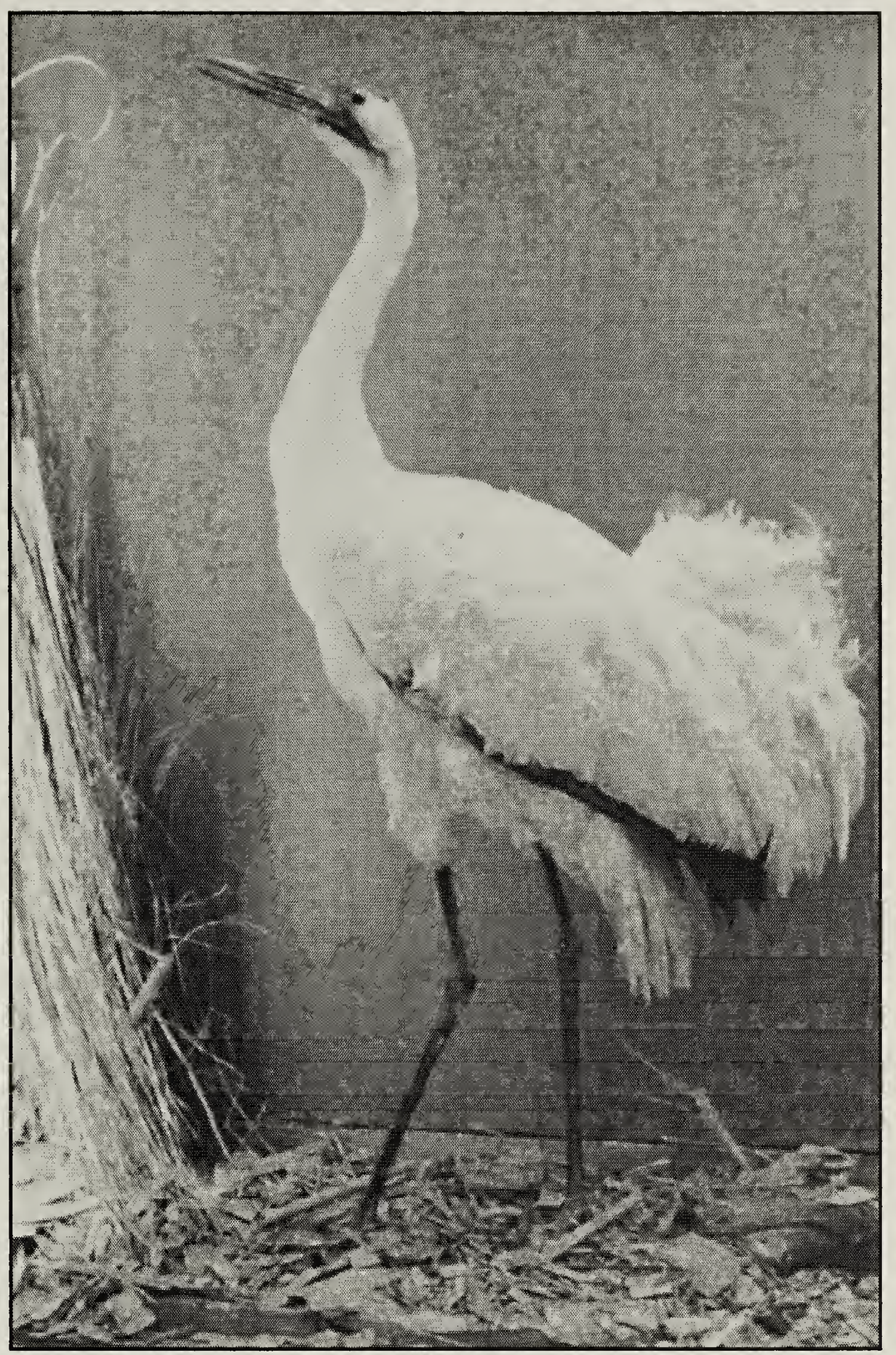

Figure 4. Whooping Crane in the Stewart-Hay Memorial Museum (SHMM 672), University of Manitoba. in the StewartHay Memorial

Museum: an adult male (labeled a female, SHMM 33) and an unsexed juvenile (SHMM 34), both without dates and collecting localities.

\section{Short-billed and Long-billed dowitchers}

These difficult-to-identify species are included in this list because the identities of four of the five specimens of dowitchers housed in the UMZM were confirmed in

August 1975 by Frank A. Pitelka (who quantified geographic variation and revised the taxonomy of the dowitcher genus Limnodromus $\left.{ }^{34}\right)$. The Short-billed Dowitchers are UMZM 1479, $6 \mathrm{~km}$ northwest of Oakland, 10 August 1974; UMZM 1480 and 1481, $16 \mathrm{~km}$ southwest of Battleford, Saskatchewan, 30 August and 3 September 1973, respectively. The Longbilled Dowitchers (identity of 1974 specimen 


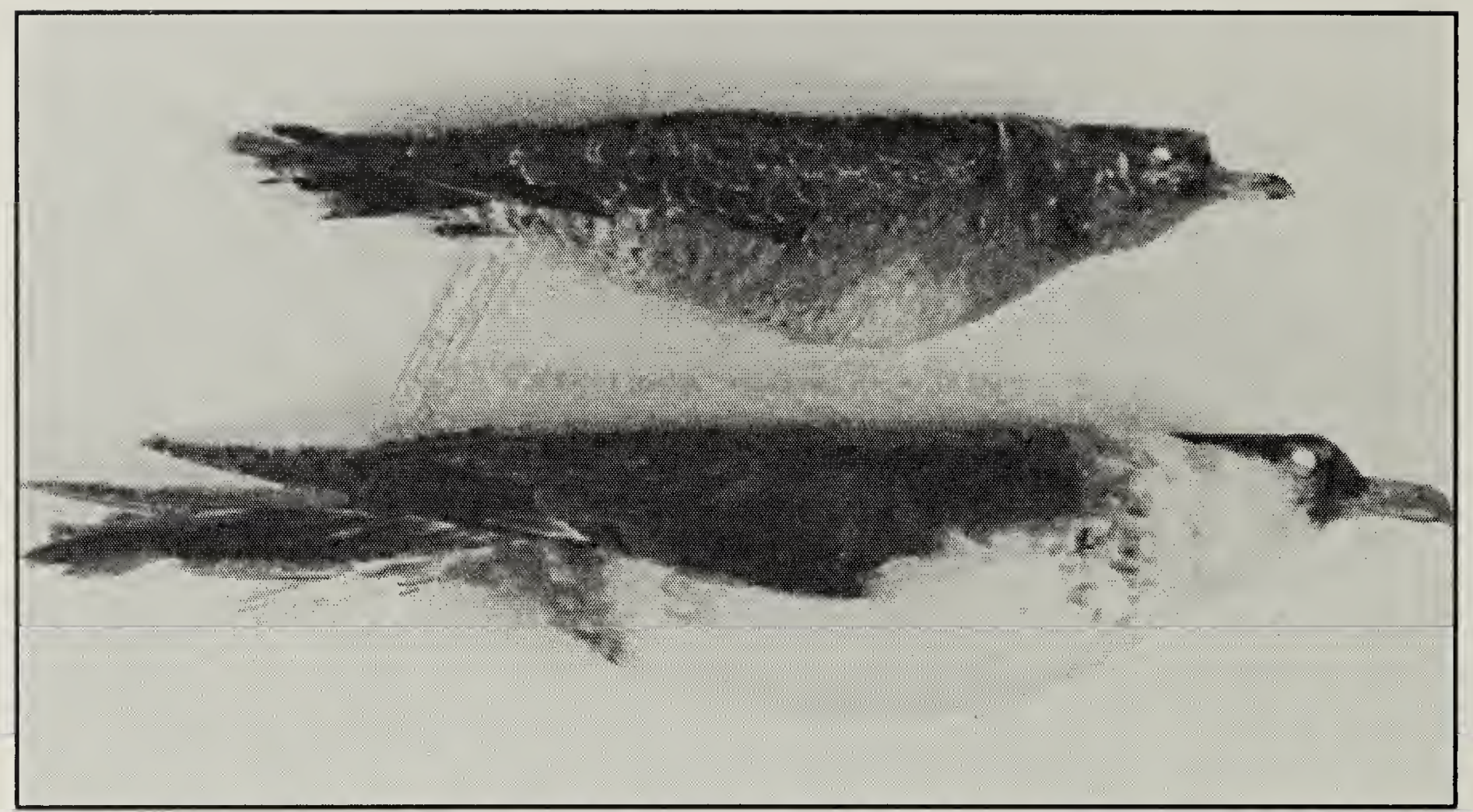

Figure 5. Above, juvenile Parasitic Jaeger (UMZM 3083), Moose Lake Provincial Park, Manitoba, 26 August 2000; below, Pomarine Jaeger(UMZM 2853), Lake Manitoba, 20 June 1992.

was not confirmed by Pitelka because it had not yet been prepared as a specimen) are UMZM 1478 and 1477, both collected at Delta Marsh, 26 July 1973 and 24 May 1974, respectively.

\section{Parasitic Jaeger}

There are more than 25 records of the Parasitic Jaeger from southern Manitoba, ${ }^{23,46}$ but few specimens. A camper found a weakened juvenile (UMZM 3083, Fig. 5, top) near the Birch Lake garbage container in Moose Lake Provincial Park near Lakeof-the-Woods on 26 August 2000. Park staff readied it for transport but it died before it could be moved (K. De Smet, pers. comm.). The bird ended up at Manitoba Conservation and was examined by G. Graham, R. Jones, and K. De Smet. The other specimen of a Parasitic Jaeger, an egg-laying female (UMZM 1047), was found dead by Dale Caswell at Cape Churchill in "spring" 1976.

\section{Pomarine Jaeger}

This is the rarest of the jaegers in southern Manitoba, with only three records, two of them from the fall. ${ }^{23.46}$ The only spring record is an adult male (UMZM 2853, Fig. 5, bottom) found dead by Glen and Robin
McMaster on the southern shore of Lake Manitoba at the Delta Marsh Field Station on 20 June 1992.

\section{Black-legged Kittiwake}

A first-year, female Black-legged Kittiwake (UMZM 2852) was found dead on a road at the Pine Falls Generating Station near Powerview on 16 November 1996. Details of the discovery and a photograph were published. ${ }^{47}$ The bird's age and the date of its occurrence coincide with the bulk of records of this species from the Prairie Provinces. ${ }^{41,47}$

\section{Ivory Gull}

The Ivory Gull was added to the list of Manitoba birds on the basis of an unsexed specimen (SHMM 80, Fig. 6) collected near Woodlands in 1915. The date 22 December 1915 is penciled on the label attached to the stand on which the bird is mounted, although the date of collection has been given by others as 27 December 1915.3.,19,23,44 On 15 May 1917, P.A. Taverner (p. 140) examined this specimen in E.W. Darbey's taxidermy establishment in Winnipeg and noted aspects of the bird's plumage, which revealed the bird was in its first year: "...face and 


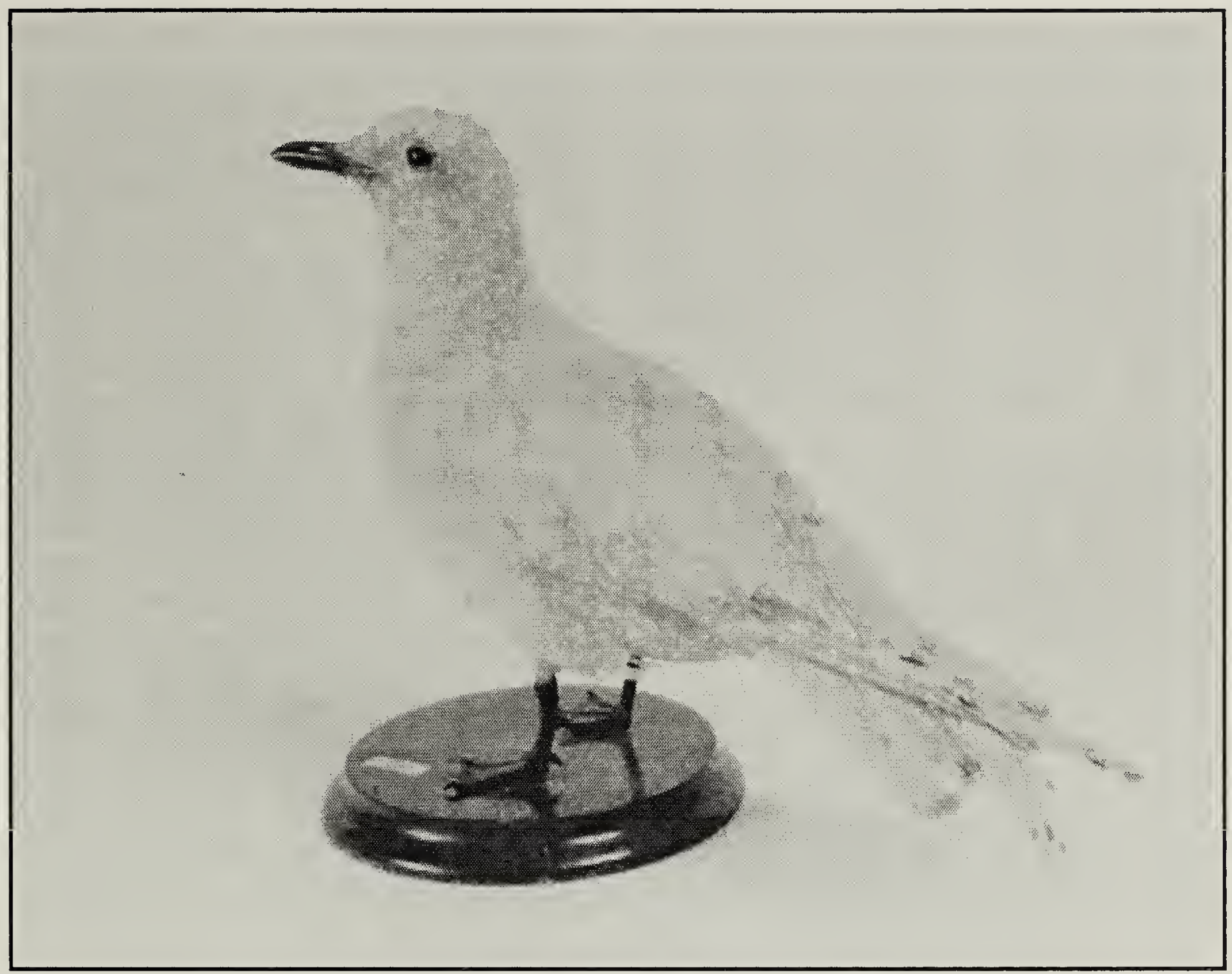

Figure 6. Subadult Ivory Gull (SHMM 80), Woodlands, Manitoba, 22 December 1915.

forehead flecked unevenly with light smoky gray, with remains of terminal tail band, and a few flecks on tertiaries, bend of wing, and lesser coverts." Some of these characteristics, for example, the once-black mottling on the face, spots on the neck and crown, and black spots and white borders of the primaries are evident from the photograph (Fig. 6) and jibe with the detailed description and photograph of a first-year bird, the first Ivory Gull recorded in California. ${ }^{51}$ Two additional specimens have been taken inland in Manitoba: an adult female (MM 1.2-941) shot at Egg Lake, near The Pas, on 11 December 1926, and another specimen (possibly MM 3.6-370 but lacking data) shot at Nelson House on 4 December 1930. Several unconfirmed sightings, principally from the Churchill area, have been reported since the first specimen was collected. ${ }^{23}$

The specimen collected in 1915 is the first confirmed occurrence of the Ivory Gull in
Manitoba, but another specimen may have been taken much earlier: a specimen from "Hudson's Bay,"15,23,24 which I have not been able to track down. Swainson and Richardson ${ }^{43}$ referred to an immature Ivory Gull in the British Museum (Natural History) that was "killed at Hudson's Bay." Correspondence with Graham Cowles (in litt., 27 April 1987) of the Sub-Department of Ornithology, British Museum (Natural History) at Tring, England, revealed that no skins of the Ivory Gull in that collection give Hudson Bay as a locality on the label. Indeed, there is no evidence that the specimen Richardson probably collected was ever at the British Museum and at the beginning of the book these authors noted that their specimens from North America had been sent to several museums and universities in Europe.

\section{Black Guillemot}

The third Black Guillemot recorded at 
Churchill in winter was found alive (after being dropped by a Common Raven) on 4 January 1991. It was transported by air to Winnipeg, cared for by staff of the Manitoba Wildlife Rehabilitation Organization, and taken to the Assiniboine Park Zoo on 9 January, ${ }^{29}$ where it died and was turned over to the museum (UMZM 2858, unsexed juvenile). A photograph of this bird taken before it died has been published. ${ }^{29}$

\section{Yellow-billed Cuckoo}

I salvaged a window-killed, adult male Yellow-billed Cuckoo (UMZM 2387) on the University of Manitoba Fort Garry campus on 3 July 1982. A statistical comparison of the measurements of this specimen and those of individuals in western and eastern populations indicate that it is referable to the eastern subspecies Coccyzus americanus americanus ${ }^{9.35}$ It is a vagrant in Manitoba, although there are a few other specimens, several sight records, and one confirmed nesting in the province. ${ }^{23}$

\section{Barn Owl}

The Barn Owl was added to the list of birds of Manitoba on the basis of an unsexed specimen (SHMM 339) shot at Ste. Anne's on 6 November 1912. The well-prepared mount (Fig. 7) originally was in the collection of taxidermist, E.W. Darbey. ${ }^{5.6}$ No other details are a va il a ble concerning the collection of this specimen. It was more than one year old, judged by the $s$ u b t l e differences in wear of the primaries $^{36}$ and the notched serrations on the flange of the talon on the middle toe. ${ }^{16}$

Other Barn Owl specimens from Manitoba have been documented, as well as several sight records and a recent pair that laid a clutch of eight eggs in the attic of a farmhouse near Springstein, about $10 \mathrm{~km}$ west of Winnipeg. ${ }^{30,32}$

Figure 7. Barn Owl (SHMM 339), Ste. Anne's, Manitoba, 6 November 1912. 
On 9 July 1994, R.W. Nero collected three of the seven unhatched eggs (UMZM 2860) that remained in this clutch. These measured $45.9 \times 32.0 \mathrm{~mm}, 47.9 \times 33.8 \mathrm{~mm}$ and $52.7 \times$ $32.3 \mathrm{~mm}$.

Another specimen of the Barn Owl came to light in the mid-1990s, under unusual circumstances. On 13 May 1995, R. Wheeldon and $\mathrm{A}$. Benoit discovered the remains of a Barn Owl (UMZM 2763) one wing, a tail and two feet (Fig. 8) - at the base of a dead tree at the interface between woodland and meadow, in La Barrière Park. The remains were eventually turned over to R. W. Nero, whose notes are catalogued with the specimen and from which I have drawn several points, and have added others to the description that follows. In addition to the remains of the owl, there were remains of other birds at the site, which suggest a feeding site and that the owl had been depredated, then scavenged. No other parts of the owl's body were found. Only three secondaries plus the bases of quills of two inner secondaries remained on the wing and all but the first three primaries were in good condition. The muscles had been removed, exposing the bones, and the humerus had been broken as if chewed. The sacrum had been cleaned of all musculature and detached from the carcass. Only one of the central rectrices remained attached to the pygostyle. Six other tail feathers were present, but the tips of their quills had been clipped off at angles as if by a knife. Both feet had been severed, apparently bitten at the distal ends of the tibiotarsi; some muscles of one metatarsus were gone. This bird also was more than one year old, with characteristics of the primaries and talons similar to those of the specimen (SHMM 339) collected in 1912.

Had the body parts of this Barn Owl been transported to La Barrière Park from elsewhere and, if so, how long had the remains been there? Nero detected evidence of scavenging by insects, as feces he believed to be from insect larvae had been deposited

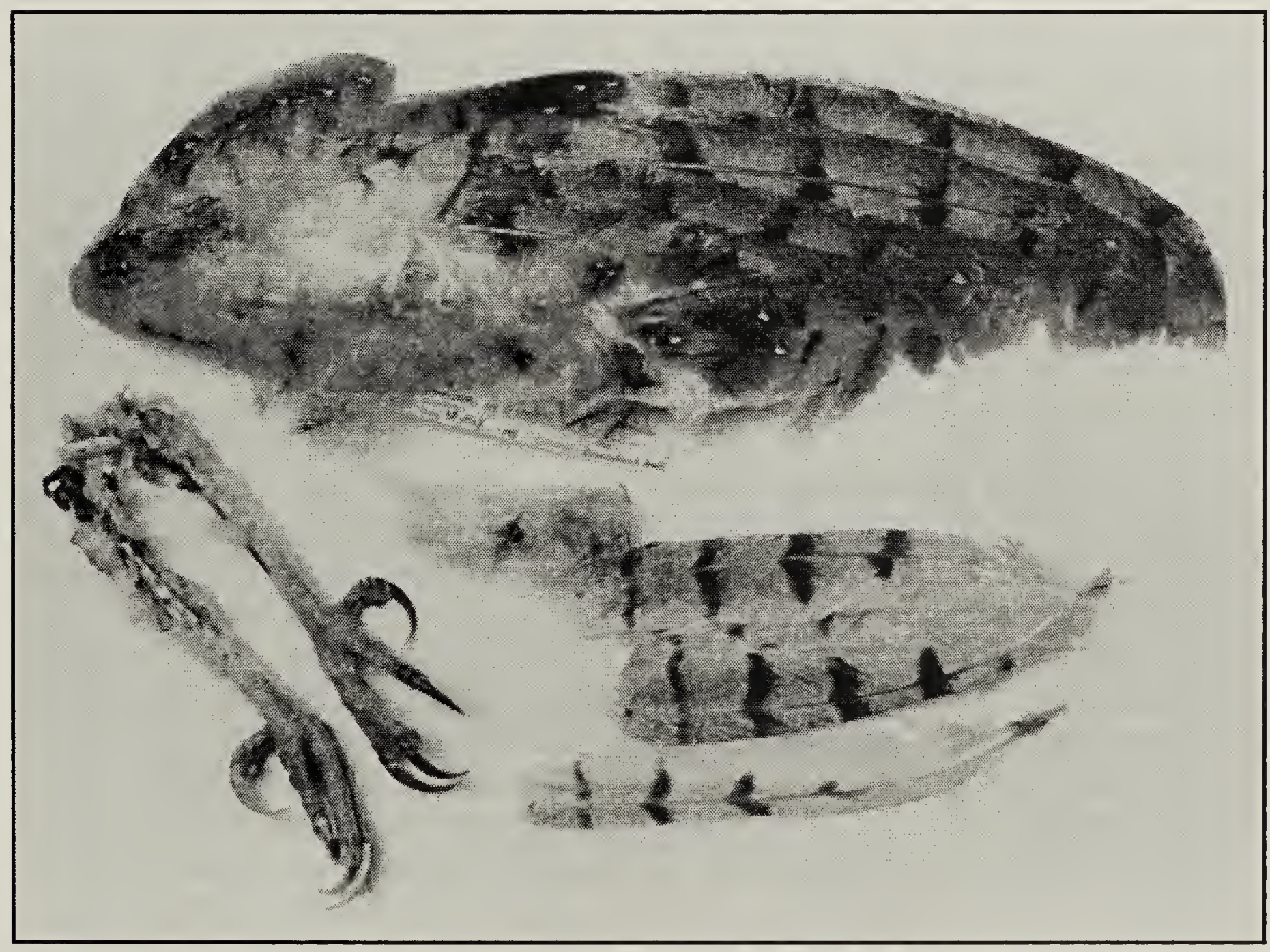

Figure 8. Remains of Barı Owl (UMZM 2763), La Barrière Park, Manitoba, May 1995. 
on the inside of the sacrum. Along with the good condition of the feathers, this suggests the remains had been there since the previous fall or even late summer, but no longer. Measurements $(\mathrm{mm})$ taken by Nero (wing chord, minimum 334; flat wing, 350; tail, minimum 135; tarsus, 90; longest (central) toe, 38 ; foot-pad, 67) suggest an adult female from the eastern population, individuals of which are generally larger than those of the Barn Owl in the west. ${ }^{25}$

\section{Great Gray Owl}

Through the efforts of R.W. Nero, the collection of Great Gray Owls at the University of Manitoba has become one of the largest in North America. Seventy-nine specimens were salvaged between 1974 and 1981 plus single specimens in 1989, 1992 and 1997, for a total of 82 specimens. About 10 specimens turned in during the 1990 s were not preserved due to limitations on storage space. In addition to 67 study skins of hatching- and after-hatching-year individuals, there is one clutch of eggs (UMZM 2934), two one-day-old chicks (UMZM 2931, 2932), one older nestling (UMZM 2779), and one recently fledged young (UMZM 2892). Also, body parts (feathers, wing(s), head, feet, etc.) were salvaged from seven individuals and are part of the collection. Twenty additional Great Gray Owls salvaged between January and April 1981 were preserved by Nero and turned over to the UMZM, along with detailed notes accompanying each specimen.

Also available for research are all of the primaries and rectrices molted by "Lady Grayl," a female Great Gray Owl that has been in captivity since being rescued as an undernourished nestling in 1984 and kept by Robert Nero. ${ }^{31}$ The date each feather was shed has been recorded.

\section{Northern Hawk Owl}

I found several contour and flight feathers of a Northern Hawk Owl (UMZM 2759) strewn on the forest floor in a woodlot along the southern edge of Delta Marsh on 19
October 2000. There are relatively few records of this species outside the boreal forest in Manitoba, ${ }^{23}$ but among them are additional records during the non-breeding season at Delta Marsh. ${ }^{50}$

\section{Boreal Owl}

An influx of Boreal Owls was recorded in the Winnipeg area over the winter of 19881989: 11 individuals (five males and six females (UMZM 2746-54, 2756-57)) were found dead and turned in to Manitoba Conservation and prepared as study skins by J.R. and P.A. Duncan. Based on the ages of the primaries, ${ }^{36}$ three of the five males were juveniles and two were after-hatchingyear adults, whereas three of the six females were juveniles and three were after-hatchingyear adults. Although this sample is small, the preponderance of adult females and juveniles of both sexes supports findings that adult male Boreal Owls tend to remain near their nest sites during the nonbreeding season, even when food is scarce, whereas females and juveniles may search widely for food. ${ }^{21,22}$ Those specimens reveal the importance of preserving salvaged specimens.

\section{Red-headed Woodpecker}

After increasing in numbers in Manitoba during the first six or seven decades of the 20th century, Red-headed Woodpeckers have become less numerous since the 1970s. ${ }^{23}$ This trend is reflected in the dates of seven roadkills (five adults, two juveniles) salvaged on trips I made each year between Winnipeg and Delta Marsh beginning in 1973. Specimens were collected between 1973 and 1985 , but since 1985 no road-kills have been found or specimens turned in. Collection details are: UMZM 997, $4.8 \mathrm{~km}$ north of St. Norbert, 5 August 1973; UMZM 998, Pigeon Lake, 9 July 1974; UMZM 1001, 15 $\mathrm{km}$ north of Anola, 7 July 1978; and UMZM 1000 (juvenile), $4.8 \mathrm{~km}$ west of Headingly, 24 August 1978; UMZM 999, 9.6 km west of Headingly, 8 August 1979; UMZM 991 (juvenile, wing salvaged), Headingly, 16 August 1979; and UMZM 2464, Komarno, 25 August 1985. 


\section{Northern Flicker}

Five specimens exhibit a mixture of characteristics of the "yellow-shafted" and "red-shafted" subspecies of the Northern Flicker, Colaptes auritus auritus and C. a. cafer, respectively. A wing (UMZM 976) was salvaged from a road-killed bird $2.5 \mathrm{~km}$ north of Glenlea on 10 April 1976 and the others (UMZM 2481, 2484, 2486, 2488) were among six flickers window-killed in Winnipeg on 26 April 1982. Four other individuals show characteristics of only yellow-shafted flickers (UMZM 2482-85), the much more common subspecies in Manitoba. ${ }^{23}$ Hybrid flickers had been taken in Manitoba at least 100 years ago. ${ }^{1}$

\section{Boreal Chickadee}

Boreal Chickadees are permanent residents of the northern coniferous forests of North America. ${ }^{8}$ However, irruptions periodically occur outside the breeding range and large numbers of individuals, mostly juveniles, ${ }^{33}$ leave the forests in fall and winter. ${ }^{8}$ In Manitoba, 1983 was such a year. A hatchingyear female (UMZM 2394) struck a window on the University of Manitoba campus in Winnipeg on 14 October and four Boreal Chickadees were banded at Delta Marsh in October. Many other Boreal Chickadees were recorded in fall 1983 at other localities in Manitoba and the Northern Great Plains region..$^{7.20}$

\section{Townsend's Solitaire}

I salvaged a window-killed, hatching-year male (UMZM 1827) in Winnipeg on 24 September 1981. At that time, there were seven records in Manitoba, including two specimens, ${ }^{13,18,38}$ plus one probable sighting. David I. MacKenzie observed one at the edge of the dune-ridge forest, Delta Marsh, on 26 and 27 October 1977. Sightings of this species have become almost annual events since the 1970s, and through the end of 2002, and the number of records had reached about 55, which includes the 1981 specimen recorded here. ${ }^{23}$ Most records of this species east of the Rocky Mountains and across the Prairie Provinces have been in the fall, but occasionally individuals are sighted in early spring. $20,23,38,40$

\section{Northern Parula}

On 26 May 2002, after a prolonged cold spell, I found a dead, adult female Northern Parula (UMZM 2681), weighing only $5.7 \mathrm{~g}$ $(1.4 \mathrm{~g}$ less than the lowest extreme given for females), ${ }^{28}$ amid leaf litter in the dune-ridge forest, Delta Marsh, immediately west of the Delta Marsh Field Station. Three Nashville Warblers (UMZM 2678-80) and one each of Palm Warbler (UMZM 2677), Wilson's Warbler (UMZM 2856), and American Redstart (UMZM 2691), found dead nearby between 22 and 25 May of the same year, were added to the UMZM collection.

Previously in the dune-ridge forest, I had watched a male Northern Parula for about 15 minutes as it sang and foraged in the outer canopy of a Green Ash on 28 May 1986. More recently, three hatching-year males were banded (DMBO): one on 23 August 1998 and two in 2003, on 31 July and 8 August. P. Viola saw one female and heard a male in the ridge forest on 22 and 25 May 2001 , respectively.

Recent observations suggest the existence of a small breeding population of Northern Parulas between Lake Manitoba and Lake Winnipeg, ${ }^{48}$ north of Delta Marsh and east of the previously documented breeding range in Manitoba. ${ }^{26}$

\section{Black-throated Blue Warbler}

I saw an adult male on the University of Manitoba campus on 29 October 1984 and undoubtedly the same bird (UMZM 2416) was found dead on 31 October in almost the same location where the individual had been seen two days earlier. This date was the latest among the more than 70 records of this species in Manitoba. ${ }^{23}$

\section{Orchard Oriole}

By the early 1970s, Orchard Orioles occurred regularly in southern Manitoba. ${ }^{23}$ 
Four of the specimens in UMZM date from 1975-1976, with one each from 1981, 1983, and 2000. Many individuals have been banded. Our first record at Delta Marsh was a hatching-year female (UMZM 1528) mistnetted on 3 August 1975. In 1976, an adult female (UMZM 1526) and a second-year male (UMZM 1527) were taken on 3 and 5 June, respectively, and several nests were discovered. ${ }^{39}$ An unsexed, hatching-year Orchard Oriole (UMZM 1525, partial skin), caught in a mist net, was killed by a Franklin's Ground Squirrel on 11 August 1976. A hatching-year male (UMZM 1814) that struck a window on the property of the Delta Waterfowl Foundation on 30 August 1981 was salvaged by J. Hochbaum, and another window-killed individual, an unsexed, hatching-year female (UMZM 2413), was salvaged in Oakland, Manitoba, about $5 \mathrm{~km}$ south of Delta Marsh on 17 August 1983. The latter had been banded (no. 1201-33130) in the ridge forest on 23 July of the same year, but had been mistakenly recorded as an after-hatching-year female when banded. Finally, an adult male (UMZM 2857) with an irreparably damaged wing was found in the dune-ridge forest on 3 June 2000. This bird retained three bicoloured (black and olive) rectrices on the left side of the tail, characteristic of the first basic plumage, whereas the other tail feathers were black with white tips, typical of males in the definitive alternate (breeding) plumage. ${ }^{37}$

\section{Acknowledgements}

Over the years, many individuals and agencies have turned in specimens to the University of Manitoba Zoology Museum. In this regard, I am especially indebted to personnel of Manitoba Conservation, The Manitoba Museum, and recently the Manitoba Wildlife Rehabilitation Organization (via Terry D. Galloway, Department of Entomology, University of Manitoba). Herbert W.R. Copland provided information and newspaper accounts of records of the Ivory Gull and Barn Owl in the files of The Manitoba Museum. Gavin Hanke, Janis Klapecki and Betty-Ann
Penner provided data for several other species in. The Manitoba Museum and permitted me to examine the collections under their care. Robert Wheeldon provided information on a Barn Owl specimen and Robert W. Nero made available his copious notes on that specimen, and read an early draft of the manuscript. Robert Barrow took the photographs of the specimens. I am grateful to Anna Leighton for carefully editing the final drafts of the manuscript. The Department of Zoology, University of Manitoba, provided funds for storage cases and for cataloging the specimens. In addition to commenting on the manuscript, Todd J. Underwood created a computer database for the entire bird study skin collection in the University of Manitoba Zoology Museum.

1. ATKINSON, G.E. 1904. Rare bird records of Manitoba. Historical and Scientific Society of Manitoba, Transaction 65: 1-12.

2. BENT, A.C. 1938. Life Histories of North American Birds of Prey. Part 2. United States National Museum Bulletin, no. 170.

3. CARTWIGHT, B.W. 1927a. Ivory Gull in Manitoba. Auk 44: 241.

4. CARTWIGHT, B.W. 1927b. "Freak" Ivory Gull (Pagophila alba). Canadian Field-Naturalist 41: 17.

5. CARTWRIGHT, B.W. 1929a. The Barn Owl (Tyto alba pratincola) in Manitoba. Auk 46: 236.

6. CARTWRIGHT, B.[W]. 1929b. Barn Owl in Manitoba. Canadian Field-Naturalist 43: 83.

7. FAANES, C.A. 1984. Changing seasons: northern Great Plains region. American Birds 38: 330-331.

8. FICKEN, M.S., M.A. MCLAREN, and J.P. HAILMAN. 1996. Boreal Chickadee (Parus hudsonicus). In: A. Poole and F. Gill (eds.) The Birds of North America, no. 254. The Academy of Natural Sciences, Philadelphia, PA, and The American Ornithologists' Union, Washington, D.C.

9. FRANZREB, K.E., and S.A. LAYMON. 1993. A reassessment of the taxonomic status of the Yellowbilled Cuckoo. Western Birds 24: 17-28.

10. FULLER, A.B. 1938. Yellow Rail at Churchill, Manitoba. Auk 55: 670-671.

11. GODFREY, W.E. 1986. The Birds of Canada, revised edition. National Museum of Natural Sciences, Ottawa, ON. 
I2. HAMILTON, R.A., and N.J. SCHMITT. 2000. Identification of Taiga and Black Merlins. Western Birds 3I : 65-67.

13. HARROLD, C.G. 1923. Notes on some interesting species. Canadian Field- Naturalist 37: 169.

14. HOUSTON, C.S. 2002. Spread and disappearance of the Greater Prairie-Chicken, Tympanuchus cupido, on the Canadian Prairies and adjacent areas. Canadian Field-Naturalist 1 I6: 1-21.

15. JEHL, J.R., JR., and B.A. SMITH. 1970. Birds of the Churchill region, Manitoba. Manitoba Museum of Man and Nature, Special Publication, no. 1.

16. JOHNSON, P.N. 1991. Development of talon flange and serrations in the Barn Owl Tyto alba: a guide to ageing. Ringing and Migration 12: 126-127.

17. LANE, J. 1962. Nesting of the Yellow Rail in southwestern Manitoba. Canadian Field-Naturalist 76: 189-191.

18. LANE, J., and D. RANDALL. 1970. Townsend's Solitaire collected at Brandon, Manitoba. Canadian Field- Naturalist 84: 59.

19. LAWRENCE, A.G. 1926. A rare Arctic straggler. Chickadee Notes, no. 30I, December 30. Winnipeg Free Press, Winnipeg, MB.

20. LEIGHTON, A.L., J. HAY, C.S. HOUSTON, J.F. ROY, and S. SHADICK (Eds.). 2002. Birds of the Saskatoon Area. Saskatchewan Natural History Society, Special Publication, no. 23.

21. LOFGREN, O., B. HORNFELDT, and B.G. CARLSSON. 1986. Site tenacity and nomadism in Tengmalm's Owl (Aegolius funereus (L.)) in relation to cyclic food production. Oecologia (Berlin) 69: 321326.

22. LUNDBERG, A. 1979. Residency, migration and a compromise: adaptations to nest-site scarcity and food specialization in three Fennoscandian owl species. Oecoligia (Berlin) 41: 273-281.

23. MANITOBA AVIAN RECORDS COMMITTEE. 2003. The Birds of Manitoba. Manitoba Naturalists Society, Winnipeg, MB.

24. MANNING, T.H. I952. Birds of the west James Bay and southern Hudson Bay coasts. National Museum of Canada Bulletin No.I25, Biological Series, no. 43.

25. MARTI, C.M. 1990. Barn Owl (Tyto alba). 1n: A. Poole and F. Gill (eds.). The Birds of North America, no. 1. The Academy of Natural Sciences, Philadelphia, PA, and The American Ornithologists' Union, Washington, D.C.

26. MCN1CHOLL, M.K., and P. TAYLOR. I982. The Northern Parula in Manitoba. Blue Jay 40: I09-119.
27. M1N1SH, B.R. 1987. The feasibility of reestablishing Greater Prairie-Chickens in Manitoba. Practicum, Natural Resources Institute, University of Manitoba, Winnipeg, MB.

28. MOLDENHAUER, R.R., and D.J. REGELSKI. 1996. Northern Parula (Parula americana). In: A. Poole and F. Gill (eds.). The Birds of North America, no. 215. The Academy of Natural Sciences, Philadelphia, PA, and The American Ornithologists' Union, Washington, D.C.

29. NERO, R.W. 1992. Second winter record of Black Guillemot at Churchill, Manitoba. Blue Jay 50: 1 I3114.

30. NERO, R.W. 1993. Probable Barn Owl records for Manitoba. Blue Jay 51: 170-171.

3I. NERO, R.W. 1994. Lady Grayl: Owl with a Mission. Natural Heritage/Natural History, Toronto, ON.

32. NERO, R.W. 1995. Barn Owl nesting in Manitoba. Blue Jay 53: 159-166.

33. PALMER, R.S. 1949. Maine Birds. Bulletin of the Museum of Comparative Zoology 102: 1-656.

34. PITELKA, F.A. 1950. Geographic variation and the species problem in the shore-bird genus Limnodromus. University of Califomia Publications in Zoology 50: 1-108.

35. PYLE, P. 1997a. Identification Guide to North American Birds. Part I. Slate Creek Press, Bolinas, CA.

36. PYLE, P. 1997b. Flight-feather molt patterns and age in North American owls. American Birding Association, Monographs in Field Ornithology, no. 2.

37. SCHARF, W.C., and J. KREN. 1996. Orchard Oriole (Icterus spurius). 1n: A. Poole and F. Gill (eds.). The Birds of North America, no. 255. The Academy of Natural Sciences, Philadelphia, PA, and The American Ornithologists' Union, Washington, D.C.

38. SEALY, S.G. 1971. The occurrences of some western birds in Saskatchewan. Blue Jay 29: 184-196.

39. SEALY, S.G. 1980. Breeding biology of Orchard Orioles in a new population in Manitoba. Canadian Field-Naturalist 94: 154-158.

40. SMITH, A.R. 1996. Atlas of Saskatchewan Birds. Saskatchewan Natural History Society, Special Publication, no. 22.

41. SMITH, A.R., and E. KUYT. 1983. Occurrences of the Black-legged Kittiwake, Rissa tridactyla, in the Prairie Provinces and north-central United States. Canadian Field-Naturalist 97: 111-113. 
42. SODHI, N., L.W. OLIPHANT, P.C. JAMES, and I.G. WARKINTIN. 1993. Merlin (Falco columbarius). In: A. Poole and F. Gill (eds.) The Birds of North America, no. 44. The Academy of Natural Sciences, Philadelphia, PA, and The American Ornithologists' Union, Washington, D.C.

43. SWAINSON, W., and J. RICHARDSON. 1831. Fauna-Boreali-Americana; or the Zoology of the Northern Parts of British America. Part Second, The Birds. John Murray, London, United Kingdom.

44. TAVERNER, P.A. 1919. The birds of Shoal Lake, Manitoba. Canadian Field-Naturalist 32: 137-144.

45. TAYLOR. P. 1983. Wings Along the Winnipeg: The Birds of the Pinawa-Lac du Bonnet Region, Manitoba. Manitoba Naturalists Society, Eco Series, no. 2.

46. TAYLOR, P. 1993. Mid-continental jaegers: a Manitoba perspective. Blue Jay 51: 157-164.
47. TAYLOR, P. 1997. A tale of two kittiwakes. Blue Jay 55: 149-151.

48. TAYLOR, P., B. SHETTLER, and C. BRADSHAW. 1997. Northern Parulas west of Lake Winnipeg. Blue Jay 55: 220-221.

49. TEMPLE, A.S. 1972. Systematics and evolution of the North American Merlins. A $\iota k$ 89: 325-338.

50. UNDERWOOD, T.J., and H.E. den HAAN. 2000. Checklist of the Birds of Delta Marsh, $3^{\text {rd }}$ edition. [Delta Marsh Bird Observatory.]

51. WEINTRAUB, J.D., and M. SAN MIGUEL. 1999. First record of the Ivory Gull in California. Western Birds 30: 39-43.

52. ZINK, R.M. 2004. The role of subspecies in obscuring avian biological diversity and misleading conservation policy. Proceedings of the Royal Society London, Series B 271: 561-564.

\section{SEARCHING FOR EDWARD CALCUTT}

\section{STUART HOUSTON and MARY I. HOUSTON, 863 University Drive, Saskatoon, SK S7N 0J8.}

Our story begins with Wells W. Cooke, North America's leading investigator of bird migration during the final two decades of the 19 th century. Cooke began collecting early spring migration dates, beginning with 13 observers in eight states in 1882, and 26 observers in 1883 . From these he calculated that birds traveled an average of 23 miles per day. Concentrating particularly on the Mississippi River valley, he was joined by three Manitoba observers in 1884 and another three in 1885 , the latter including for the first time, Edward Calcutt. Calcutt lived just east of the Saskatchewan-Manitoba boundary near "Shell River post office," 1 and a mile east of Minniska post office which was established in 1890 (8 km north of present Russell). Copies of Calcutt's 1885 migration dates were made available to Ernest Thompson [Seton] when he published Birds of Manitoba in $1891 .^{4}$

In 1975, when we began updating the Yorkton area bird records, we realized that the Calcutt records from Shell River might fall near the Saskatchewan boundary. At our request, Chan Robbins at the Patuxent Wildlife Research Center in Laurel, Maryland, sent us copies of the Calcutt records and correspondence. From these we learned that the Calcutt homestead was ten miles east of the Saskatchewan boundary, on section 26-21-28 WPM (west of the principal meridian or W1). Calcutt had, for those times, dates for an unusually large list of species (130).

\section{Calcutt's Migration Dates}

Since Calcutt was a farmer working outdoors much of the day, with bush and a small lake visible from his house (Figure 1), most species should have been recorded on the day they arrived. Those interested in climatic change will note that most species in the accompanying table, especially the earliest arrivals, came later in the spring than they do now over one century later.

Calcutt used many species names that are no longer familiar, but added marginal notes 